\title{
Ceruloplasmin Regulates Iron Levels in the CNS and Prevents Free Radical Injury
}

\author{
Bharatkumar N. Patel, Robert J. Dunn, Suh Young Jeong, Qinzhang Zhu, Jean-Pierre Julien, and \\ Samuel David \\ Centre for Research in Neuroscience, The Montreal General Hospital Research Institute and McGill University, Montreal, \\ Quebec, Canada, H3G 1A4
}

\begin{abstract}
Ceruloplasmin is a ferroxidase that oxidizes toxic ferrous iron to its nontoxic ferric form. We have previously reported that a glycosylphosphatidylinositol-anchored form of ceruloplasmin is expressed in the mammalian CNS. To better understand the role of ceruloplasmin in iron homeostasis in the CNS, we generated a ceruloplasmin gene-deficient $\left(C p^{-1-}\right)$ mouse. Adult $\mathrm{Cp}^{-1-}$ mice showed increased iron deposition in several regions of the CNS such as the cerebellum and brainstem. Increased lipid peroxidation was also seen in some CNS regions. Cerebellar cells from neonatal $\mathrm{Cp} p^{-1-}$ mice were also more susceptible to oxidative stress in vitro. $\mathrm{Cp}^{-1-}$ mice showed
\end{abstract}

Iron plays an important role in many biological processes. It is an essential cofactor for various enzymes, including ribonucleotide reductase and aconitase, and its presence in heme imparts hemoglobin the ability to transport oxygen and enables cytochrome oxidase to reduce oxygen to water. The oxidation-reduction reactions of iron are fundamental to its role as a cofactor. However, this also makes free iron highly toxic because of its ability to generate free radicals. In particular, ferrous [Fe (II)] iron can generate the highly toxic hydroxyl and superoxide free radicals in the presence of hydrogen peroxide or molecular oxygen. Consequently, iron metabolism is tightly regulated by various proteins that transport, sequester, and mobilize iron (De Silva et al., 1996).

Transferrin, the major iron-transporting protein in plasma, transports iron from sites of storage, such as the liver, to tissues using iron. The ferroxidase ceruloplasmin $(\mathrm{Cp})$, which is produced by the liver and secreted into the plasma, also plays an important role in the movement of iron. By oxidizing the ferrous [Fe (II)] form of iron to the ferric [Fe (III)] form, Cp promotes iron loading onto transferrin, which only binds the ferric form of the metal (Osaki et al., 1966). In addition, $\mathrm{Cp}$ is an effective antioxidant, because of its ability to oxidize highly toxic ferrous iron to the relatively nontoxic ferric form and thus help prevent oxidative damage to proteins, lipids, and DNA (Gutteridge, 1992).

Ceruloplasmin is expressed by astrocytes in the brain, cerebellum, and retina and by the epithelial cells of the choroid plexus

Received Jan. 11, 2002; revised May 7, 2002; accepted May 9, 2002.

This work was supported by a grant from the Canadian Institutes of Health Research and the Parkinson's Disease Foundation (S.D.). B.N.P. was supported by studentships from the National Centers of Excellence NeuroScience Network and the David and Dorothy Lam Award from the NeuroScience Canada Foundation.

Correspondence should be addressed to Dr. Samuel David, Centre for Research in Neuroscience, Montreal General Hospital Research Institute, 1650 Cedar Avenue, Montreal, Quebec, Canada H3G 1A4. E-mail: sdavid11@po-box.mcgill.ca. Copyright (C) 2002 Society for Neuroscience 0270-6474/02/226578-09\$15.00/0 deficits in motor coordination that were associated with a loss of brainstem dopaminergic neurons. These results indicate that ceruloplasmin plays an important role in maintaining iron homeostasis in the CNS and in protecting the CNS from ironmediated free radical injury. Therefore, the antioxidant effects of ceruloplasmin could have important implications for various neurodegenerative diseases such as Parkinson's disease and Alzheimer's disease in which iron deposition is known to occur.

Key words: iron; neurodegeneration; free radicals; lipid peroxidation; ferroxidase; aceruloplasminemia; Parkinson's disease; oxidative stress

(Klomp et al., 1996; Patel and David, 1997; Patel et al., 2000). Although hepatocytes in the liver produce a secreted form of $\mathrm{Cp}$ found in serum that does not cross the blood-brain barrier, astrocytes express an alternatively spliced, glycosylphosphatidylinositol (GPI)-anchored form of Cp (Patel and David, 1997; Patel et al., 2000). This GPI-anchored form of $\mathrm{Cp}$ is the predominant form expressed in the brain (Patel et al., 2000) and is likely to play an important role in iron homeostasis and antioxidant defense in the CNS. The full-length cDNA for human GPI-Cp has been reported recently (Hellman et al., 2002).

The importance of $\mathrm{Cp}$ in vivo is most clearly illustrated by studies of patients with aceruloplasminemia, a hereditary deficiency of Cp caused by mutations in the $C p$ gene (Miyajima et al., 1987; Harris et al., 1995; Morita et al., 1995; Yoshida et al., 1995; Gitlin, 1998). Patients with this disorder have massive iron deposition in a number of organs, including the brain and liver. The iron deposition in the brain leads to neurodegeneration and neurological symptoms, such as motor incoordination and other motor deficits, between the ages of 45 and 55 years. The severe iron accumulation in these patients suggests that $\mathrm{Cp}$ prevents iron accumulation in vivo. Indeed, a recent study of $\mathrm{Cp}^{-1-}$ mice showed that the iron that accumulates in the liver can be released when these mice are treated with ceruloplasmin (Harris et al., 1999).

We now report that increased iron accumulation and free radical injury occur in the CNS of $\mathrm{Cp}^{-/-}$mice. In addition, we present in vitro data that provide direct evidence that CNS tissue from $C p^{-1-}$ mice is more susceptible to iron-mediated free radical injury. The $C p^{-1-}$ mouse offers a good model for the study of the human disease aceruloplasminemia and can provide insights into the pathogenesis and secondary damage that may occur in other neurodegenerative diseases, such as Parkinson's disease, Alzheimer's disease, and amyotrophic lateral sclerosis, in which iron deposition occurs. 


\section{MATERIALS AND METHODS}

Generation of $\mathrm{Cp}^{-/-}$mice. To construct a gene-targeting vector, a mouse 129/Sv genomic library in Lambda Dash II (Stratagene) was screened with a probe to the first exon of the rat $C p$ gene (Fleming and Gitlin, 1990). The two longest positive clones, containing inserts of 11 and $12 \mathrm{~kb}$, were mapped with restriction enzymes. A BglII-NheI fragment containing the first exon was replaced with a neo cassette (Promega) in the orientation opposite to that of the $C p$ gene to produce the targeting vector (see Fig. 1A). The linearized targeting construct was electroporated into R1 embryonic stem (ES) cells as described (Joyner, 1993).

ES cell clones resistant to G418 (Life Technologies) were selected. Genomic DNA was isolated from these clones and digested with EcoRI. Southern blot analysis was performed using a probe to the mouse genomic sequence upstream of the sequence used in the targeting construct to identify clones with a homologous recombination event. Two positive ES cell clones were microinjected into $\mathrm{C} 57 \mathrm{BL} / 6 \mathrm{~J}$ blastocysts that were then implanted into pseudopregnant $\mathrm{BALB} / \mathrm{c}$ mice. The resulting male chimeras were then mated with $\mathrm{C} 57 \mathrm{BL} / 6 \mathrm{~J}$ females, and the resulting F1 animals were genotyped by Southern blot analysis to identify heterozygotes, which were back-crossed to C57BL/6J animals. After one or more rounds of back-crossing, the resulting heterozygous mice were mated, and the resulting mice were genotyped by Southern blot analysis or PCR and subsequently used for analysis. All protocols for mice were in accordance with the Canadian Council on Animal Care guidelines and approved by the McGill University Animal Care Committee.

Western blot analysis. Western blots were performed using serum from $C p^{+/+}$and $C p^{-1-}$ mice to determine whether $\mathrm{Cp}$ protein expression was absent in $C p^{-/-}$mice. Serum $(0.1 \mu \mathrm{l})$ diluted in Tris-buffered saline was subjected to SDS-PAGE, and Western blot analysis was performed using a rabbit anti-human $\mathrm{Cp}$ antibody (Dako) as described previously (Patel and David, 1997).

Iron histochemistry. Mice were perfused with $0.1 \mathrm{M}$ phosphate buffer, $\mathrm{pH} 7.2$, followed by $4 \%$ paraformaldehyde in $0.1 \mathrm{M}$ phosphate buffer, $\mathrm{pH}$ 7.2. Iron was detected in cryostat sections of the liver using a modified Perl's stain for iron (Smith et al., 1997). For this, tissue sections were rehydrated in deionized water and incubated with a $7 \%$ solution of potassium ferrocyanide in $3 \% \mathrm{HCl}$ for $60 \mathrm{~min}$. Sections were then rinsed and counterstained with $1 \%$ neutral red and coverslipped. Iron histochemistry on the cerebellum and brainstem was performed using an enhanced Perl's stain that is more sensitive than the one described above. For this, tissue sections were washed in PBS and then incubated in $4 \%$ potassium ferrocyanide in $4 \% \mathrm{HCl}$ for $1 \mathrm{hr}$. After rinsing in PBS, tissue sections were incubated with unactivated diaminobenzidine (DAB) containing $1 \%$ nickel chloride for $15 \mathrm{~min}$. This was followed by a $15 \mathrm{~min}$ incubation with activated DAB and counterstaining with neutral red. Tissue sections of wild-type and knock-out mice were picked up on the same slide to permit monitoring and detection of nonspecific staining.

Immunohistochemistry. Tyrosine hydroxylase (TH) immunohistochemistry was done to detect dopaminergic neurons in the midbrain. Cryostat sections $(15-20 \mu \mathrm{m})$ of $4 \%$ paraformaldehyde-fixed brain from $C p^{+/+}$and $C p^{-1-}$ mice were processed for immunohistochemistry as described previously (Ousman and David, 2000). Tissue sections were incubated overnight with a polyclonal rabbit anti-TH antibody (1:200; Chemicon, Temecula, CA). Binding of the primary antibody was detected using a biotinylated secondary antibody followed by avidin-biotin complex conjugated to peroxidase and visualized as described previously (Ousman and David, 2000).

Total non-heme iron determination. Total non-heme iron (TNHI) was measured as described previously by Torrance and Bothwell (1980), with slight modifications. Briefly, tissues were removed from mice after perfusion with PBS. Tissues were dried for $48 \mathrm{hr}$ at $45^{\circ} \mathrm{C}$, weighed, and digested for $48 \mathrm{hr}$ in $10 \%$ trichloroacetic acid $/ 10 \% \mathrm{HCl}$ at $65^{\circ} \mathrm{C}$. Two hundred microliters of the extract were then added to $1 \mathrm{ml}$ of chromogen solution $(0.01 \%$ bathophenanthroline-disulfonic acid, $0.1 \%$ thioglycolic acid, $7 \mathrm{~m}$ sodium acetate) and incubated for $10 \mathrm{~min}$, and the absorbance was measured at $535 \mathrm{~nm}$. A certified iron standard from Sigma (kit 565A) was used to determine iron levels. A standard curve performed for iron concentrations between 10 and $500 \mu \mathrm{g} / \mathrm{ml}$ revealed a linearity of response with a slope of $\sim 1$. Samples were diluted appropriately to fall within the linear range, and a $100 \mu \mathrm{M} \mathrm{FeCl}{ }_{3}$ solution was used as an additional internal control. TNHI values were expressed as micrograms of iron per gram of dry weight.

Lipid peroxidation assay. Lipid peroxidation was assessed using the thiobarbituric acid reactive substances (TBARS) assay that detects malondialdehyde (MDA), an end product of the peroxidation of polyunsat- urated fatty acids and related esters (Bowie et al., 1997). Briefly, tissues were homogenized with $0.5 \%$ SDS in PBS, and $100 \mu$ lof the sample was incubated with $900 \mu \mathrm{l}$ TBARS reagent $(0.4 \%$ 2-thiobarbituric acid, $0.5 \%$ $\mathrm{SDS}, 10 \%$ acetic acid, $\mathrm{pH} 3.5)$, incubated for $60 \mathrm{~min}$ at $95^{\circ} \mathrm{C}$, and centrifuged, and the absorbance of the supernatant was read at $532 \mathrm{~nm}$. The amount of TBARS was quantified using a standard curve of MDA [malonaldehyde bis (dimethyl acetal)] and expressed as nanomoles of MDA per gram of protein.

Serum iron measurement and hematological analysis. Serum iron levels and total iron-binding capacity were determined using a kit from Sigma. Hematological parameters, such as hematocrit, hemoglobin levels, red blood cell counts, white blood cell counts, and platelet counts, were performed using an automated counter using fresh heparinized blood.

Behavioral assays. To assess motor skills, mice were put on a $3-\mathrm{cm}-$ diameter rod that was covered with a thin rubber mat for grip and rotated at $20 \mathrm{rpm}$ (rotary rod assay) (Steele et al., 1998). The mice were given a training period and subsequently put on the rod for a maximum duration of $3 \mathrm{~min}$. The mice were allowed to rest for $2 \mathrm{~min}$, and the test was repeated five more times.

To assess whether the $C p^{-/-}$mice had impaired activity levels, mice were placed in cages containing a hamster wheel that was connected to a meter (Liu et al., 1997). The total distance for the $12 \mathrm{hr}$ night cycle was recorded for each mouse, and the test was performed for two additional nights. The average distance per $12 \mathrm{hr}$ night cycle for each mouse was used for the data analysis.

To determine whether the $C p^{-1-}$ mice had reduced muscle strength, the mice were placed on a thin metal grid attached to weights of increasing mass. After the mice had grasped the grid, they were gently raised by the base of their tails (Frey et al., 2000), and the maximum weight held by the mice for a period of $5 \mathrm{sec}$ was recorded.

In vitro $\mathrm{H}_{2} \mathrm{O}_{2}$ toxicity assay. Dissociated cultures of the cerebellum were prepared from postnatal day 9 mice using previously described protocols (Mittal and David, 1994). Dissociations were performed using $0.25 \%$ trypsin in HBSS for $10 \mathrm{~min}$ at room temperature. Cells were plated into poly-L-lysine-coated 24-well tissue culture plates (Linbro) at a density of $8 \times 10^{5}$ cells per well and grown in DMEM containing $10 \%$ fetal bovine serum, vitamins, and penicillin/streptomycin. These cultures contain a mixture of mainly neurons and astrocytes, with the latter expressing the GPI-anchored form of Cp (Patel and David, 1997).

After $4 \mathrm{~d}$ in culture, the cerebellar cell cultures were washed twice with DMEM, and fresh serum-free Neurobasal Medium containing G-5 supplement, L-glutamine, vitamins, and penicillin/streptomycin (Life Technologies) was added. After $2 \mathrm{hr}$, fresh serum-free medium containing $\mathrm{H}_{2} \mathrm{O}_{2}$ at either 50 or $250 \mu \mathrm{M}$ was added to the cultures in quadruplicate wells. In some experiments, the iron chelator desferrioxamine mesylate (DFO) was included at $125 \mu \mathrm{M}$ and added immediately before the addition of $\mathrm{H}_{2} \mathrm{O}_{2}$. After $24 \mathrm{hr}$, cultures were washed with DMEM and incubated with 3-(4,5-dimethylthiazol-2-yl)-2,5-diphenyltetrazolium bromide [(MTT); $0.5 \mathrm{mg} / \mathrm{ml}$ in DMEM] for $90 \mathrm{~min}$ (Hansen et al., 1989). The medium was then removed, and the cells were solubilized with $1 \mathrm{ml}$ isopropanol/0.1N HCl. The blue color reaction in the solution was quantified with a spectrophotometer at $570 \mathrm{~nm}$, and the results were normalized to control cultures not treated with $\mathrm{H}_{2} \mathrm{O}_{2}$.

For immunostaining, the cerebellar cells were plated on poly-L-lysinecoated $15-\mathrm{mm}$-round glass coverslips at $5 \times 10^{5}$ cells per coverslip. Cells were cultured and treated with $50 \mu \mathrm{M} \mathrm{H}_{2} \mathrm{O}_{2}$ as described above. At the termination of the experiment, cultures were fixed and permeabilized and double labeled with a monoclonal anti-neurofilament antibody, RT97, to label neurons and a rabbit polyclonal anti-glial fibrillary acidic protein antibody to label astrocytes. Primary antibodies were visualized using appropriate rhodamine- and fluorescein-conjugated secondary antibodies, and the nuclei were labeled with nuclear yellow (Hoechst S769121).

\section{RESULTS}

To generate $\mathrm{Cp}$-deficient mice, a targeting vector that contained a neo gene cassette flanked on either side by a $3 \mathrm{~kb}$ ceruloplasmin genomic sequence was used to replace a $3 \mathrm{~kb}$ endogenous fragment containing the first exon of the ceruloplasmin gene (Fig. $1 A$ ). This strategy eliminates both the transcription start site as well as the first exon that codes for the signal peptide, thus eliminating the possibility that a truncated protein might be produced. Southern blotting demonstrated the successful gener- 

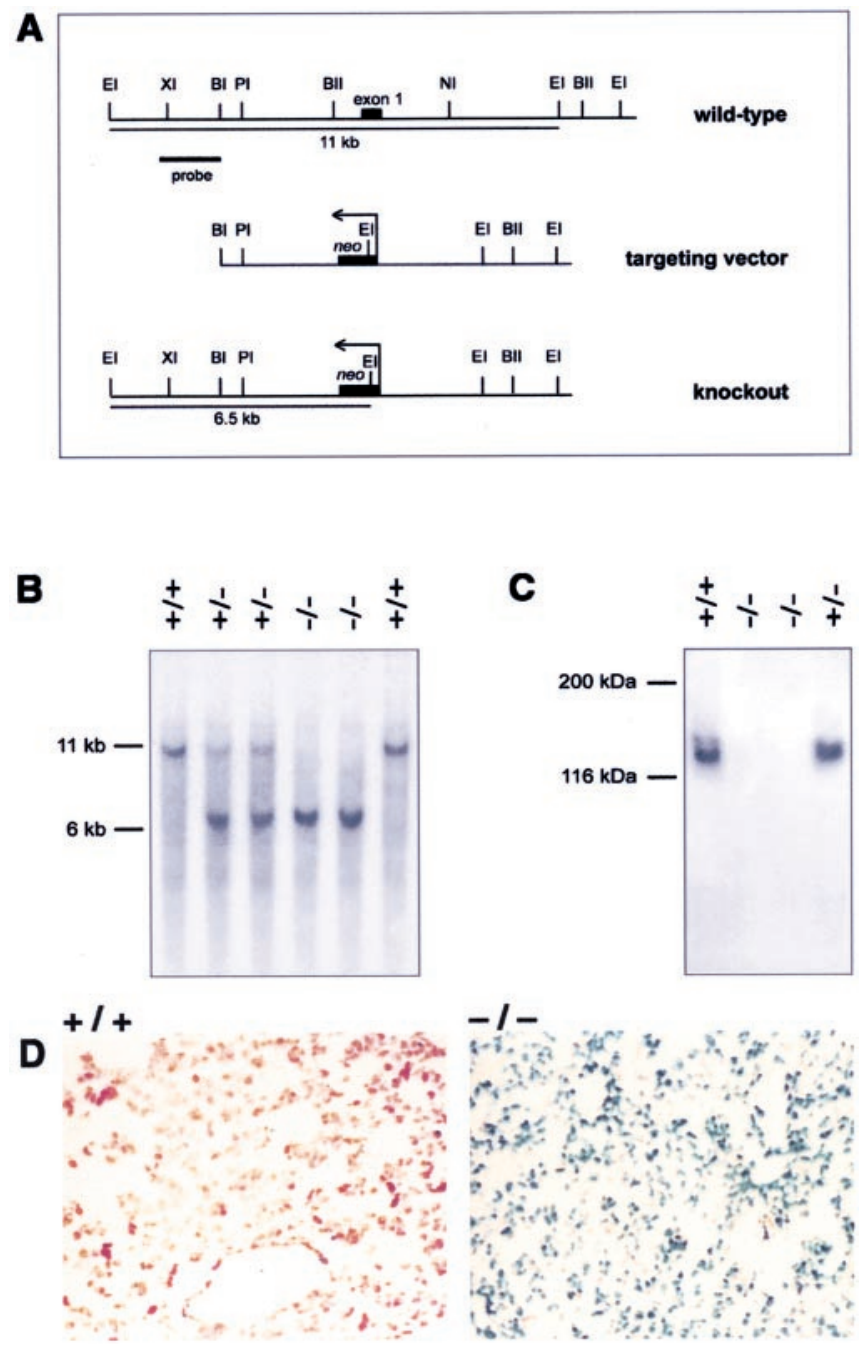

Figure 1. Generation of $C p^{-/-}$mice. $A$, The targeting vector was generated by replacing the $3 \mathrm{~kb} \mathrm{BglII}-N h e \mathrm{I}$ fragment containing the first exon of the $C p$ gene with a neo cassette. Homologous recombination of the targeting vector in ES cells leads to the generation of a $6.5 \mathrm{~kb}$ EcoRI fragment compared with a $11 \mathrm{~kb}$ wild-type fragment detected using a 1.5 $\mathrm{kb}$ probe upstream of the targeting vector (probe). BI, BglI; BII, BglII; EI, EcoRI; NI, NheI; PI, PstI; XI, XhoI. B, Southern blot of EcoRI-digested genomic DNA from $\mathrm{F} 2$ animals using the probe shown in $A$. $C$, Western blot of serum using a rabbit anti-C p polyclonal antibody. Both $C p^{+/+}$and $C p^{+/-}$mice contain large amounts of $\mathrm{Cp}$ in the serum, whereas $C p^{-1-}$ mice lack Cp. D, Histological sections of the livers of 16 -month-old $C p^{+/+}$ and $C p^{-1-}$ mice stained for iron using Perl's stain. The sections were counterstained with neutral red. The liver from a $\mathrm{Cp}^{+/+}$mouse $(+/+)$ does not show staining for iron. Only the neutral red counterstaining is visible. In contrast, the liver from a $C p^{-1-}(-/-)$ mouse shows strong labeling for iron, which appears as blue staining.

ation of $C p^{-1-}$ mice and was used to genotype mice for analysis (Fig. $1 B$ ). Western blotting of the serum confirmed the absence of $\mathrm{Cp}$ in $\mathrm{Cp}^{-/-}$mice (Fig. $1 C$ ).

\section{Iron homeostasis is disrupted in $\mathrm{Cp}^{-1-}$ mice}

Because severe hepatic iron accumulation is a hallmark of $\mathrm{Cp}$ deficiency in humans, and because the clinical symptoms are generally detected later in life between the ages of 45 and 55 years, we examined the liver of 16-month-old $\mathrm{Cp}^{-1-}$ mice for iron content. Abundant iron accumulation was observed within hepatocytes in the liver of $C p^{-/-}$mice using the Perl's stain (Fig. 1D).
In contrast, very little staining was seen in the liver of $C p^{+/+}$mice (Fig. 1D).

$C p^{-/-}$mice were examined for changes in various hematological parameters associated with a lack of $\mathrm{Cp}$. Compared with $C p^{+/+}$mice, $C p^{-1-}$ mice had a severe reduction in serum iron levels (Table 1 ). This $\sim 6.5$-fold reduction in serum iron levels is also reflected in the lower transferrin saturation (the percentage of total iron binding sites in transferrin loaded with iron) in these mice (4 vs 27\%). No significant changes in serum hemoglobin levels (Table 1) or in several other hematological parameters, such as hematocrit or white blood cell count, were observed (data not shown). Using an assay that measures TNHI, iron levels were found to be highly elevated in the liver of $\mathrm{Cp}^{-1-}$ mice compared with $C p^{+/+}$controls. $C p^{-1-}$ mice had a 10.6 -fold increase in hepatic TNHI at 16 months (Table 1). Iron levels in the spleen were not statistically significantly different between the two groups of mice.

\section{Iron accumulates in the CNS of $\mathrm{Cp}^{-1-}$ mice}

Because iron accumulation in the CNS is a characteristic feature of patients with aceruloplasminemia, we examined various regions of the nervous system, including different parts of the brain and spinal cord and the retina, for iron accumulation. The total non-heme iron content of the brainstem and cerebellum was significantly elevated in the $C p^{-1-}$ mice at 16 months, with the brainstem showing a $103 \%$ increase and the cerebellum a $35 \%$ increase over $C p^{+/+}$mice (Fig. $2 A$ ). The spinal cord was also affected in $\mathrm{Cp}^{-1-}$ mice, with the cervical spinal cord demonstrating a $116 \%$ increase and the thoracic spinal cord an $84 \%$ increase over $\mathrm{Cp}^{+/+}$mice (Fig. $2 A$ ). The retina showed a $93 \%$ elevation in iron content in the $C p^{-/-}$mice. The levels of iron in other parts of the nervous system, such as the cortex, caudate/putamen, olfactory bulb, and lumbar spinal cord, were not significantly different between $C p^{-/-}$and $C p^{+/+}$mice.

Iron deposition in the cerebellum and midbrain was also assessed histochemically using a modified Perl's technique. Marked iron deposition was detected in both regions in 24-month-old $C p^{-1-}$ mice. The deposits in the cerebellum were prominent in the granule cell layer (Fig. $3 A, B$ ) and the deep cerebellar nuclei. Iron staining was also seen in the region of the substantia nigra (data not shown). Iron levels are known to be high in the normal substantia nigra although this iron is bound to protein and therefore not toxic. On the other hand, the iron deposits in $\mathrm{Cp}^{-1-}$ mice are likely to be in the redox active state because the viability of these neurons is severely reduced (see below).

\section{Increased free radical-mediated damage occurs in the CNS of $\mathrm{Cp}^{-1-}$ mice}

Because the lack of $\mathrm{Cp}$ leads to increased iron deposition in some regions of the CNS and because $\mathrm{Cp}$ is an antioxidant, we assessed lipid peroxidation in different parts of the CNS as evidence of oxidative damage. Significant elevations in lipid peroxidation were observed in the olfactory bulb ( $84 \%$ increase) and the cervical spinal cord (58\% increase) (Fig. $2 \mathrm{~B}$ ) of $\mathrm{Cp}^{-/-}$mice at 16 months. Despite having elevated levels of iron in $C p^{-/-}$mice, the cerebellum, brainstem, thoracic spinal cord, and retina did not show significant increases in lipid peroxidation by the assay that was used. It is possible that the gradual accumulation of iron over a period of months may result in a low level of cell damage occurring over a prolonged period of time, which may not be detected by the assay used. This is supported by the findings that despite the lack of an increase in lipid peroxidation products in 


\begin{tabular}{|c|c|c|c|c|c|c|c|}
\hline Mice & $\begin{array}{l}\text { Serum iron } \\
(\mu \mathrm{g} / \mathrm{dl})\end{array}$ & TIBC $(\mu \mathrm{g} / \mathrm{dl})$ & $\begin{array}{l}\text { Transferrin } \\
\text { saturation }(\%)\end{array}$ & $\mathrm{Hb}(\mathrm{gm} / \mathrm{dl})$ & $\begin{array}{l}\text { Liver TNHI } \\
(\mu \mathrm{g} / \mathrm{gm})\end{array}$ & $\begin{array}{l}\text { Spleen TNHI } \\
(\mu \mathrm{g} / \mathrm{gm})\end{array}$ & $\begin{array}{l}\text { Kidney TNHI } \\
(\mu \mathrm{g} / \mathrm{gm})\end{array}$ \\
\hline$C p^{+/+}$ & $106 \pm 24$ & $399 \pm 77$ & $26.6 \pm 6.6$ & $13.7 \pm 0.8$ & $203 \pm 24$ & $4385 \pm 1456$ & $213 \pm 18$ \\
\hline$C p^{-1-}$ & $16 \pm 5.3^{*}$ & $399 \pm 89$ & $3.9 \pm 1.9^{*}$ & $13.5 \pm 1.8$ & $2156 \pm 482^{*}$ & $1389 \pm 616$ & $248 \pm 31$ \\
\hline
\end{tabular}

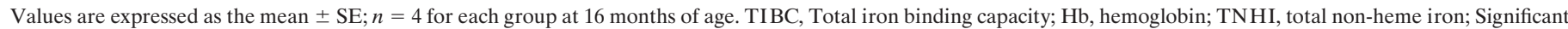
differences are observed between $C p^{+/+}$and $C p^{-/-}$mice for serum iron, transferrin saturation, and liver TNHI ( ${ }^{*} p \leq 0.05$, Student's $t$ test).

A Total Non-Heme Iron in 16-month old Mice

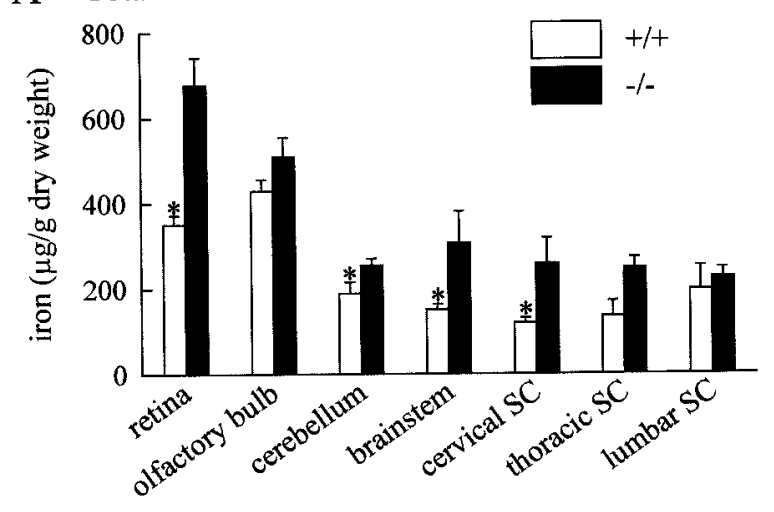

B Lipid Peroxidation in 16-month old Mice

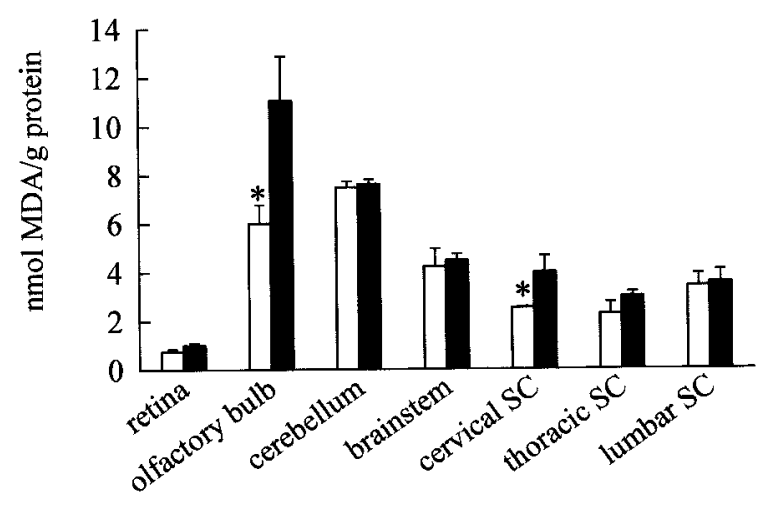

Figure 2. Iron content and lipid peroxidation in CNS. A, The total non-heme iron content of different brain regions from $\mathrm{Cp}^{+/+}$and $\mathrm{Cp}^{-1-}$ mice. Values are shown as the mean \pm SE. $n=4$ for both groups of mice ( ${ }^{*} p \leq 0.05$; Student's $t$ test). $B$, Levels of lipid peroxidation as assessed by measuring the levels of 2-thiobarbituric acid reactive substances in tissue homogenates of different brain regions from wild-type and knock-out mice are displayed. Values are shown as the mean \pm SE. $n=4$ for both groups of mice ( ${ }^{*} p \leq 0.05$; Student's $t$ test).

the brainstem and retina, there was loss of tyrosine hydroxylasepositive dopaminergic neurons in the brainstem (Fig. 3C,D) and histological evidence of neurodegeneration in the inner nuclear layer of the retina (Fig. $4 A-D$ ). Ceruloplasmin mRNA has been shown to be expressed mainly in this layer of the retina (Klomp and Gitlin, 1996).

On the other hand it is also possible that in some CNS regions other antioxidant mechanisms may protect cells from ironmediated oxidative damage. This possibility is supported by the fact that although massive iron accumulation occurs in the liver of $\mathrm{Cp}^{-1-}$ mice, it does not show a significant increase in lipid peroxidation. In addition, although the olfactory bulb did not show a significant increase in iron content in $C p^{-/-}$mice, it showed a marked elevation in lipid peroxidation, suggesting that in some CNS regions there may be a change in the redox active state of iron.

\section{Neural cells from $\mathrm{Cp}^{-1-}$ mice are more susceptible to free radical injury}

Because $\mathrm{Cp}$ is an antioxidant and GPI-anchored $\mathrm{Cp}$ is expressed by astrocytes, we examined whether neural cells from $C p^{-/-}$mice have an increased susceptibility to oxidative stress. Dissociated neonatal cerebellar cell cultures from $\mathrm{Cp}^{-/-}$and $C p^{+/+}$mice were treated with $\mathrm{H}_{2} \mathrm{O}_{2}$, and their viability was assessed $24 \mathrm{hr}$ later. Cerebellar cultures from $\mathrm{Cp}^{+/+}$mice were not affected by $50 \mu \mathrm{M} \mathrm{H}_{2} \mathrm{O}_{2}$. In contrast, cultures from $\mathrm{Cp}^{-/-}$ mice showed a $45 \%$ reduction in viability compared with untreated cultures using the MTT assay (Fig. $5 A$ ). Cell counts showed a $90 \%$ loss in viability of $\mathrm{Cp}^{-/-}$cultures (588 \pm $17 / \mathrm{mm}^{2}$ untreated; $60 \pm 5 / \mathrm{mm}^{2}$ treated) but no loss in cultures of cells from $\mathrm{Cp}^{+/+}$mice $\left(530 \pm 22 / \mathrm{mm}^{2}\right.$ untreated; $533 \pm$ $30 / \mathrm{mm}^{2}$ treated). The more severe effect detected with the cell counts is likely caused by the loss of very weakly attached cells that are lost because of the extra washing steps required to stain the cells for counting. Double-immunofluorescence staining for astrocytes and neurons showed that although the viability of both cell types was reduced in $\mathrm{Cp}^{-/-}$by such treatment, the neuronal loss was more severe (Fig. 6). At the higher $(250 \mu \mathrm{M})$ concentration of $\mathrm{H}_{2} \mathrm{O}_{2}$, cultures from both $\mathrm{Cp}^{-/-}$ and $C p^{+/+}$mice displayed a drastic reduction in viability (Fig. $5 A)$. This result suggests that at this high concentration of $\mathrm{H}_{2} \mathrm{O}_{2}$, the protection mediated by $\mathrm{Cp}$ is insufficient to prevent cellular injury. Alternatively, $\mathrm{Cp}$ itself might be damaged by the high $\mathrm{H}_{2} \mathrm{O}_{2}$ and would therefore no longer be protective. The latter possibility is supported by the observation that $\mathrm{H}_{2} \mathrm{O}_{2}$ at high concentrations leads to the release of redox-active copper atoms within $\mathrm{Cp}$ and the fragmentation of the protein (Choi et al., 2000).

The reduction in viability of the cerebellar cultures from $C p^{-1-}$ mice caused by $\mathrm{H}_{2} \mathrm{O}_{2}$ in vitro is likely to be caused by the production of toxic hydroxyl radicals. $\mathrm{H}_{2} \mathrm{O}_{2}$ can react with a number of different redox-active metals to generate this free radical (Winterbourn, 1995). To determine whether the toxicity of $\mathrm{H}_{2} \mathrm{O}_{2}$ was mediated by iron, cerebellar cultures were treated with $\mathrm{H}_{2} \mathrm{O}_{2}$ in the presence of the iron chelator DFO, and cell viability was assessed $24 \mathrm{hr}$ later. DFO completely prevented the decrease in viability of the $C p^{-/-}$cultures treated with $50 \mu \mathrm{M} \mathrm{H}_{2} \mathrm{O}_{2}$ (Fig. $5 B)$. The iron chelator only partially prevented the decrease in viability of both the $C p^{-/-}$and $C p^{+/+}$cultures treated with 250 $\mu \mathrm{M} \mathrm{H}_{2} \mathrm{O}_{2}$. However, the level of rescue was higher in cultures from $C p^{+/+}$control mice compared with those from $C p^{-/-}$mice. High concentrations of $\mathrm{H}_{2} \mathrm{O}_{2}$ can promote the release of iron from the iron-DFO complex (Borg and Schaich, 1986) and may underlie the partial rescue at the higher $\mathrm{H}_{2} \mathrm{O}_{2}$ concentration. 

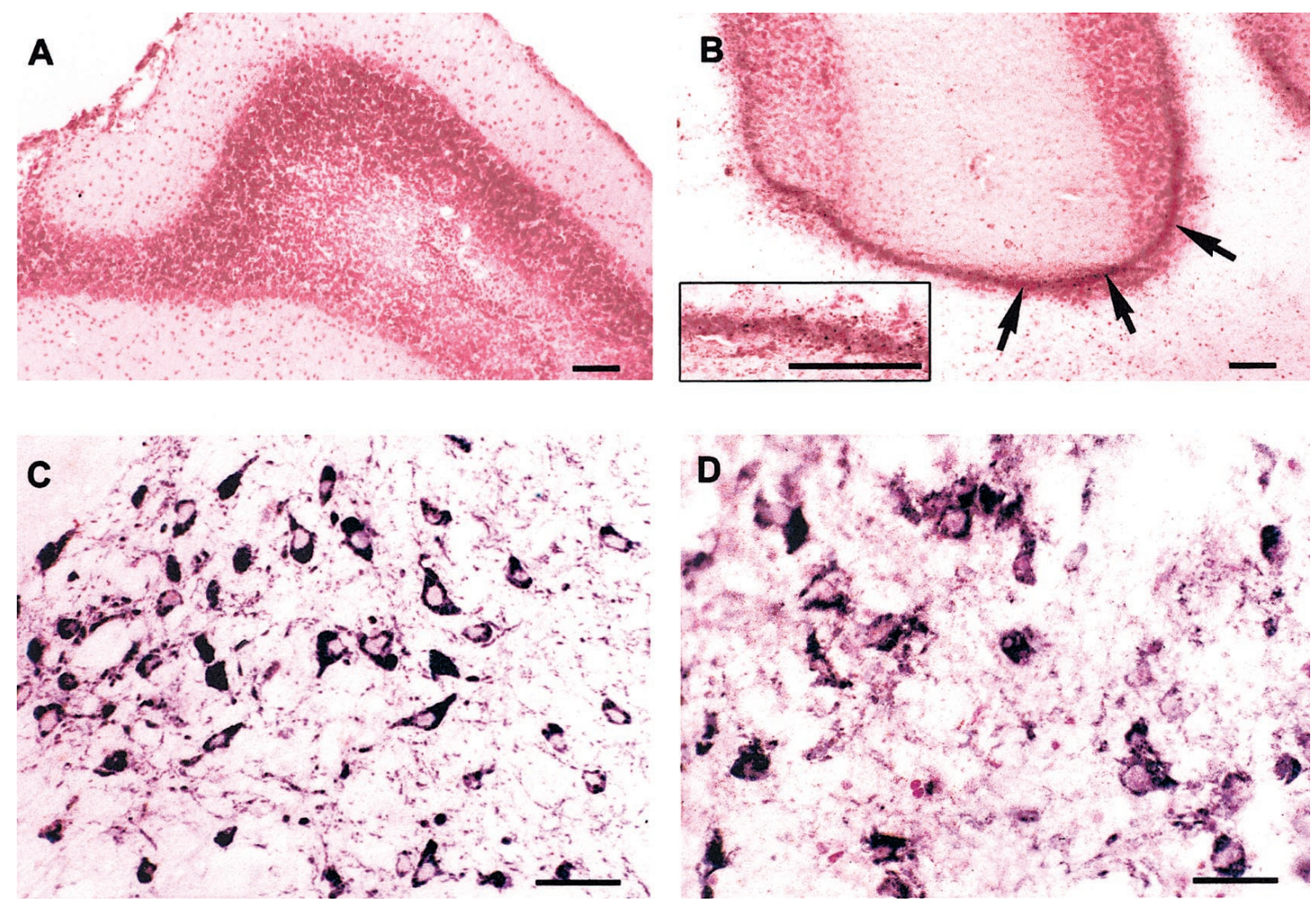

Figure 3. Iron histochemistry and Neurodegeneration. $A, B$, Iron histochemistry of the cerebellum of $C p^{+/+}(A)$ and $C p^{-/-}$mice $(B)$. Iron deposits, which appear brown in color (arrows), are seen in the granule cell layer in $C p^{-1-}$ mice $(B)$. The inset in $B$ shows these iron deposits at higher magnification. Scale bar, $100 \mu \mathrm{m} . C, D$, TH ${ }^{+}$dopaminergic neurons in the substantia nigra of $C p^{+/+}(C)$ and $C p^{-/-}$mice $(D)$. There are fewer TH neurons in the null mice $(D)$, and those present appear to be undergoing degeneration. Scale bars, $100 \mu \mathrm{m}$.

\section{$\mathrm{Cp}^{-1-}$ mice have impaired motor coordination}

To assess whether the increased accumulation of iron and increased oxidative injury in the CNS of $\mathrm{Cp}^{-1-}$ mice affect motor behavior, we performed the rotary rod assay on mice at 16 months. $C p^{-1-}$ mice had an impaired ability to remain on the rotary rod compared with the $C p^{+/+}$mice. Although the $C p^{+/+}$ mice remained on the rotary rod for $>3 \mathrm{~min}$, the $\mathrm{Cp}^{-/-}$mice remained on the rod for $<25 \mathrm{sec}$, indicating a severe loss of motor coordination in these mice (Fig. 7). $\mathrm{Cp}^{+/+}$and $\mathrm{Cp}^{-/-}$mice did not demonstrate statistically significant differences in strength $(121 \pm 13$ vs $103 \pm 9 \mathrm{gm})$ or locomotory endurance (3823 \pm 733 vs $6062 \pm 2647 \mathrm{~m}$ ), the latter assessed using the hamster wheel assay. These results suggest that the motor deficit in $\mathrm{Cp}^{-/-}$mice observed using the rotary rod assay was not caused by increased fatigability or decreased strength.

\section{DISCUSSION}

Increased iron accumulation in the CNS of $\mathrm{Cp}^{-1-}$ mice

Iron accumulates in different parts of the CNS in Cp-deficient mice to varying extents. The accumulation is high in the brainstem, retina, and cervical and thoracic spinal cord, with approximately a doubling of the iron content. A significant increase in iron is also found in the cerebellum. The iron deposition seen in these mice is similar in some respects to that observed in patients with aceruloplasminemia, because these patients also display iron accumulation in the brainstem, cerebellum, and retina (Miyajima et al., 1987; Harris et al., 1995; Morita et al., 1995; Yoshida et al., 1995). However, other regions such as the caudate and putamen, which show iron accumulation in aceruloplasminemia patients, appeared to have normal iron levels in $C p$ null mice. Overall, the extent of iron accumulation in the $\mathrm{CNS}$ of $\mathrm{Cp}^{-/-}$mice appears to be less than that observed in patients with aceruloplasminemia, because in the latter the iron accumulation is observable at the gross anatomical level in autopsy samples of the brain (Morita et al., 1995). In humans, neurological symptoms are manifested only between the age of 45 and 55 years (Miyajima et al., 1987; Morita et al., 1995; Yoshida et al., 1995), indicating that severe iron accumulation in the CNS takes several decades. The shorter life span of mice may account for the lower levels of iron accumulation in $\mathrm{Cp}^{-1-}$ mice.

The iron accumulation in some regions of the CNS of $\mathrm{Cp}^{-/-}$mutant mice, such as the cerebellum and brainstem, may contribute to the deficit in motor coordination observed using the rotary rod assay. This motor deficiency is somewhat similar to the behavioral deficits observed in patients with aceruloplasminemia (Yoshida et al., 1995; Okamoto et al., 1996). Although an increase in lipid peroxidation was not observed in the cerebellum of $\mathrm{Cp}^{-1-}$ mice, the in vitro experiments indicate that cerebellar cells are susceptible to iron-mediated oxidative stress. Iron does not accumulate in tissues such as muscle or kidney of $\mathrm{Cp}^{-/-}$mice (data not shown), indicating that iron accumulation is not a generalized nonspecific phenomenon. In addition, iron accumulation in the CNS of $\mathrm{Cp}^{-1-}$ mice is not caused by high serum load, because serum iron is markedly decreased. 

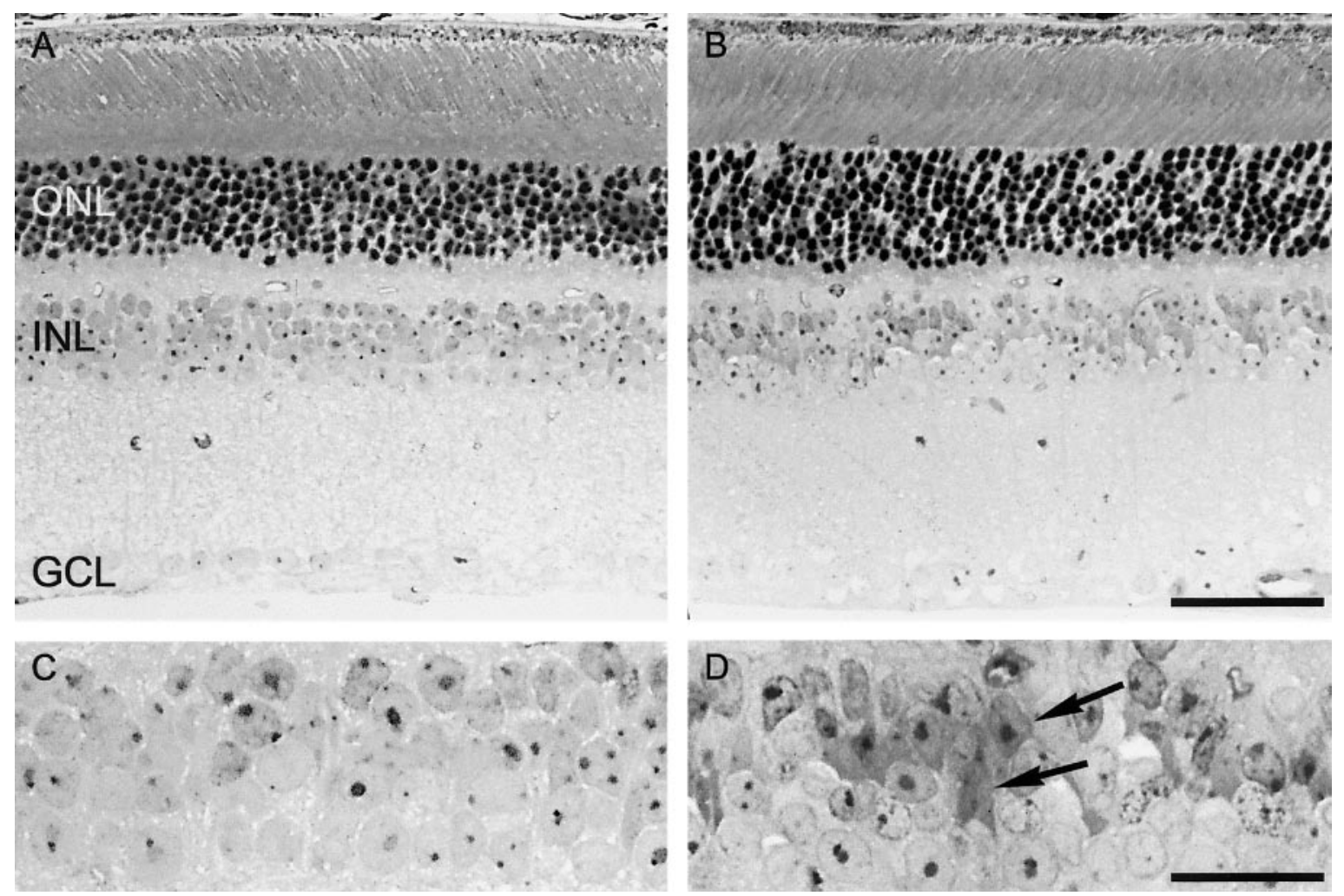

Figure 4. Retinal degeneration. $A, B$, Retina of 18-month-old $C p^{+/+}(A)$ and $C p^{-1-}$ mice $(B)$ in Epon-embedded sections stained with toluidine blue. Neurodegenerative changes are seen in the inner nuclear layer $(I N L)$ of $C p^{-1-}$ mice $(B)$. $O N L$, Outer nuclear layer; $G C L$, ganglion cell layer. $C, D$, Higher magnification of the inner nuclear layer of $C p^{+/+}$and $C p^{-/-}$mice, respectively. Neurons in this layer in wild-type mice are large rounded cells with a prominent nucleolus $(C)$. In contrast, in $C p^{-1-}$ mice many of the cells in this layer show condensed chromatin and dark cytoplasmin $(D$, arrows). Cells with small, irregularly shaped nuclei that are likely to be macrophages are also present in $C p^{-1-}$ mice $(D)$. Scale bars (shown in $B$ for $A, B$ ): 50 $\mu \mathrm{m}$; (shown in $D$ for $C, D$ ): $20 \mu \mathrm{m}$.

\section{Cp prevents oxidative damage in the CNS}

Because the increase in iron in the CNS might lead to increased oxidative stress caused by the reaction of ferrous iron with oxygen and endogenously produced peroxides, we looked for signs of increased oxidative injury in $\mathrm{Cp}^{-1-}$ mice. Surprisingly, significantly elevated levels of lipid peroxidation were seen only in the olfactory bulb and the cervical spinal cord. Although the increased lipid peroxidation in the cervical spinal cord was associated with an accumulation of iron, the olfactory bulb did not show an increase in iron. Because $\mathrm{Cp}$ is a ferroxidase that oxidizes highly toxic ferrous [Fe (II)] iron to the ferric [Fe (III)] form, it is a potent antioxidant. Therefore, the increased lipid peroxidation observed in the olfactory bulb may be attributable to an increase in the ratio of $\mathrm{Fe}$ (II)/Fe (III), caused by the absence of the ferroxidase activity of $\mathrm{Cp}$, rather than to an increase in the quantity of iron.

Despite showing iron accumulation, the cerebellum, brainstem, thoracic spinal cord, and retina did not display a significant elevation in lipid peroxidation. This may be attributable to regional differences in the capacity to manage iron and oxidative stress. For example, different regions of the CNS vary in their susceptibility to iron-dependent lipid peroxidation and in their antioxidant potential (Hussain et al., 1995; Surai et al., 1999). In addition, different regions of the CNS also vary in the expression of ferritin and thus may differ in their capacity to bind iron and render it nontoxic (Han et al., 2000). On the other hand, the gradual accumulation of iron over months may result in a low level of cell and tissue damage over a prolonged period that may be difficult to detect by measuring lipid peroxidation products.
This is supported by the evidence of neurodegeneration of dopaminergic neurons in the substantia nigra in the brainstem and of neurons in the inner nuclear layer of the retina. Interestingly, in the retina, ceruloplasmin mRNA expression is detected mainly in the inner nuclear layer (Klomp and Gitlin, 1996).

That $\mathrm{Cp}$ is an effective antioxidant in vivo is supported by the in vitro experiments using neonatal cerebellar cultures. These cultures contain astrocytes that express Cp in vivo (Klomp and Gitlin, 1996; Klomp et al., 1996) and in vitro (Zahs et al., 1993; Patel and David, 1997). We have shown previously that GPI-anchored Cp, which is expressed by astrocytes, is the predominant form of this protein expressed in the CNS (Patel et al., 2000). Cerebellar cultures from $\mathrm{Cp}^{-1-}$ mice were susceptible to $50 \mu \mathrm{M} \mathrm{H}_{2} \mathrm{O}_{2}$, demonstrating a significant decrease in viability. In contrast, $C p^{+/+}$cultures were unaffected, indicating that $\mathrm{Cp}$ protects these cells from free radical injury. The decrease in viability of cerebellar cultures from $\mathrm{Cp}^{-1-}$ mice mediated by $50 \mu \mathrm{M} \mathrm{H}_{2} \mathrm{O}_{2}$ could be completely prevented by DFO, a cell-permeable iron chelator. These data indicate that the $\mathrm{H}_{2} \mathrm{O}_{2}$ toxicity is mediated by iron, most likely involving the production of highly toxic hydroxyl radicals via the Fenton reaction (Borg and Schaich, 1986).

\section{Role of $\mathrm{Cp}$ in vivo}

Our data on $\mathrm{Cp}^{-1-}$ mice support the earlier findings by Harris et al. (1999) indicating that $\mathrm{Cp}$ is essential for iron homeostasis in non-neural tissues. In addition, we show that $\mathrm{Cp}$ plays a similar role in the CNS. Cp likely plays an important role in loading iron 

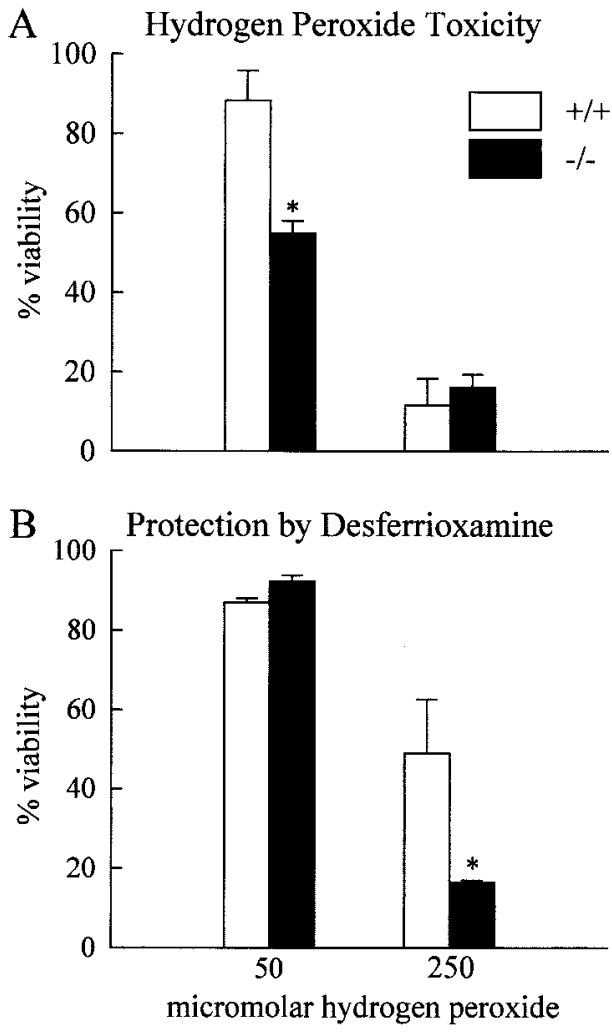

Figure 5. Susceptibility of cerebellar cultures to $\mathrm{H}_{2} \mathrm{O}_{2}$ toxicity. A, Cultures of dissociated cerebellum were treated with $\mathrm{H}_{2} \mathrm{O}_{2}$, and their viability was assessed using MTT assay. Viability is expressed relative to untreated $\left(0 \mu \mathrm{M} \mathrm{H}_{2} \mathrm{O}_{2}\right)$ control cultures and is shown as the mean $\pm \mathrm{SE}$. Results are from three separate experiments. There is a significant decrease in cell viability in cultures of cerebellar cells from $C p^{-1-}$ mice as compared with those from $C p^{+/+}$mice treated with $50 \mu \mathrm{M} \mathrm{H}_{2} \mathrm{O}_{2}\left({ }^{*} p \leq\right.$ 0.05; Student's $t$ Test). $B$, Cultures of dissociated cerebellum were treated with $\mathrm{H}_{2} \mathrm{O}_{2}$ in the presence of $125 \mu \mathrm{M}$ DFO mesylate. Viability was assessed as above and is the result of three separate experiments. DFO treatment eliminated the decrease in viability of the knockout cultures mediated by the $50 \mu \mathrm{M} \mathrm{H} \mathrm{H}_{2} \mathrm{O}_{2}$ concentration. DFO partially prevented the decrease in viability caused by the $250 \mu \mathrm{M} \mathrm{H}_{2} \mathrm{O}_{2}$ concentration, and it rescued the cultures from $\mathrm{Cp}^{+/+}$mice to a significantly greater extent $\left({ }^{*} p \leq 0.05 ;\right.$ Student's $t$ test).

onto transferrin, and this helps mobilize iron out of hepatocytes. This is supported by the observation that $\mathrm{Cp}$ enhances the efflux of iron out of hepatocyte cell lines in combination with transferrin in vitro (Young et al., 1997; Richardson, 1999). Furthermore, Harris et al. (1999) reported recently that Cp administered to $\mathrm{Cp}$ knock-out mice can mobilize iron out of the liver and temporarily restore normal iron homeostasis. As expected, we observed a marked reduction in serum iron in our $\mathrm{Cp}^{-/-}$mice that is similar to that seen in patients with aceruloplasminemia. However, Harris et al. (1999) did not observe any differences in serum iron in their $\mathrm{Cp}^{-/-}$and $\mathrm{Cp}^{+/+}$mice. Differences in the mouse strains (C57BL/6J and black Swiss-Webster) may underlie the observed differences in serum iron levels, but the mechanism whereby the mice of Harris et al. (1999) are able to maintain apparently normal serum iron levels is not known. Although there are differences in the gene targeting strategies that were used in the two studies, ceruloplasmin could not be detected by Western blotting in the serum of either type of $\mathrm{Cp}^{-1-}$ mice.

How $\mathrm{Cp}$ prevents iron accumulation in the CNS is not known. Iron uptake by the brain appears to be mediated primarily by

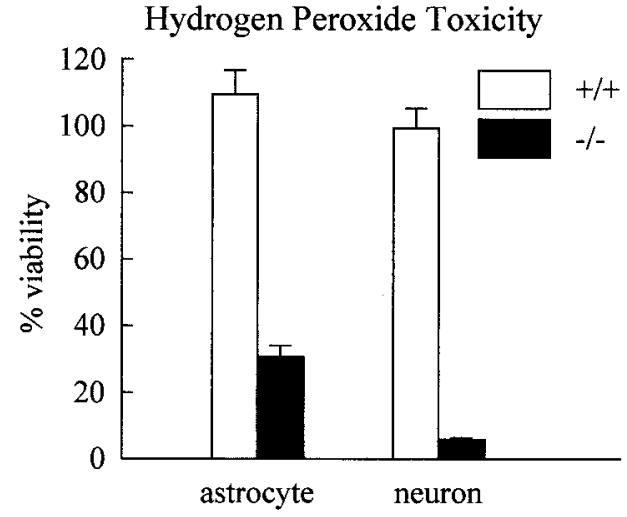

Figure 6. Counts of astrocyte and neuronal populations in cerebellar cultures from $C p^{+/+}$and $C p^{-/-}$mice treated with $50 \mu \mathrm{M} \mathrm{H}_{2} \mathrm{O}_{2}$ indicate that although the viability of both cell types is reduced in cultures of $C p^{-1-}$ mice, the loss of neurons is more drastic than that of astrocytes. Results are presented as percentage viability compared with untreated cultures.

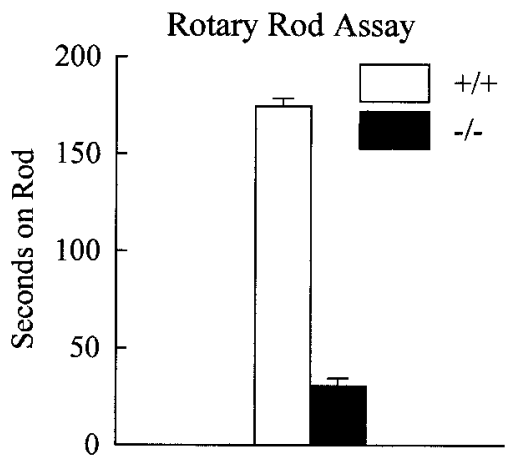

Figure 7. Tests of motor coordination. Motor coordination of $\mathrm{Cp}^{+/+}$and $C p^{-1-}$ mice was assessed using the rotary rod assay. Mice were placed on a rotating rod, and the time, in seconds, that the mice remained on the rod without falling off, up to a maximum of $180 \mathrm{sec}$, was recorded. Mice of 16 months of age were used. The results are the shown as the mean $\pm \mathrm{SE}$; $n=4$ for each group. A significant impairment in the ability of $C p^{-/-}$ mice to remain on the rotary rod compared with $C p^{+/+}$mice is observed ( $p \leq 0.05$; Student's $t$ test).

transferrin receptors located on the brain capillary endothelial cells (Malecki et al., 1999) as well as on certain neural cells (Roskams and Connor, 1992). Other non-transferrin-mediated iron uptake mechanisms may also exist, such as via the iron transporter DMT1 (Williams et al., 2000). GPI-Cp could play a role in limiting the amount of ferrous iron available for transport via DMT1, which has specificity for ferrous iron (Andrews, 1999). The efflux of iron out of CNS cells may occur via transporters such as Ireg1/ferroportin1, a membrane protein that has been shown to transport ferrous iron out of intestinal epithelial cells (Donovan et al., 2000; McKie et al., 2000). GPI-ceruloplasmin in the brain could also potentially play a role in controlling the efflux of ferrous iron via Ireg1 by rapidly oxidizing it to the ferric form as it exits at the cell surface. Such a mechanism may prevent iron accumulation in the normal CNS and lead to accumulation in the $\mathrm{Cp}$-null mice and in humans with aceruloplasminemia. Hephaestin, an integral membrane protein with ferroxidase activity that is found in intestinal epithelial cells, has homology to $\mathrm{Cp}$ and appears to mediate iron efflux from gut epithelial cells (Vulpe et al., 1999; Frazer et al., 2001). Mice lacking hephaestin accumulate iron in the gut caused by impaired egress of iron from intestinal enterocytes (Vulpe et al., 1999). In the CNS, 
GPI-anchored $\mathrm{Cp}$, which is expressed on the surface of astrocytes, could play a similar role in the efflux of iron out of the CNS.

\section{CONCLUSIONS}

Our data indicate that $\mathrm{Cp}$ is an effective antioxidant in the CNS in vivo and protects neural cells from oxidative stress. The antioxidant function of $\mathrm{Cp}$ is likely to be particularly crucial during CNS injury, such as ischemia or mechanical trauma, when levels of free iron and reactive oxygen species, including $\mathrm{H}_{2} \mathrm{O}_{2}$, increase (Hyslop et al., 1995; Palmer et al., 1999). During such injuries, the levels of $\mathrm{Cp}$ are also likely to increase because $\mathrm{Cp}$ is an acutephase protein. Indeed, levels of $\mathrm{Cp}$ increase in the retina after optic nerve crush (Levin and Geszvain, 1998).

The pathological changes observed in patients with aceruloplasminemia and in $C p^{-1-}$ mice share similarities with other neurodegenerative diseases. Iron accumulation occurs in the substantia nigra in Parkinson's disease, in the cortex and amyloid plaques in Alzheimer's disease, and in the spinal cord in amyotrophic lateral sclerosis (Gerlach et al., 1994). In addition, levels of free radicals and markers of oxidative injury are also elevated in these disorders (Olanow, 1993; Boll et al., 1999). Whether a reduction in $\mathrm{Cp}$ levels contributes to the pathology of these neurodegenerative diseases is not yet known. However, levels of $\mathrm{Cp}$ are reduced in the cortex in Alzheimer's disease (Connor et al., 1993), and the ferroxidase activity of $\mathrm{Cp}$ is reduced in the cerebrospinal fluid in Parkinson's disease (Boll et al., 1999). It is therefore possible that a reduction in $\mathrm{Cp}$ may contribute to the neurodegenerative process in these disorders by leading to an increase in the levels of ferrous iron, which can promote the generation of toxic free radicals. Thus, in addition to providing insights into the human disease aceruloplasminemia, $C p^{-1-}$ mice could also serve as a useful model to study the role of $\mathrm{Cp}$ in the more common neurodegenerative diseases. Furthermore, these mice could potentially be used to test novel therapeutic strategies to prevent iron-mediated free radical injury in the CNS.

\section{REFERENCES}

Andrews NC (1999) The iron transporter DMT1. Int J Biochem Cell Biol 31:991-994.

Boll M-C, Sotelo J, Otero E, Alcaraz-Zubeldia M, Rios C (1999) Reduced ferroxidase activity in the cerebrospinal fluid from patients with Parkinson's disease. Neurosci Lett 265:155-158.

Borg DC, Schaich KM (1986) Prooxidant action of desferrioxamine: Fenton-like production of hydroxyl radicals by reduced ferrioxamine. J Free Radic Biol Med 2:237-243.

Bowie AG, Moynagh PN, O'Neill LAJ (1997) Lipid peroxidation is involved in the activation of NF-kappaB by tumor necrosis factor but not interleukin-1 in the human endothelial cell line ECV304. Lack of involvement of $\mathrm{H}_{2} \mathrm{O}_{2}$ in NF-kappaB activation by either cytokine in both primary and transformed endothelial cells. J Biol Chem 272:25941-25950.

Choi SY, Kwon HY, Kwon OB, Eum WS, Kang JH (2000) Fragmentation of human ceruloplasmin induced by hydrogen peroxide. Biochimie 82:175-180.

Connor JR, Tucker P, Johnson M, Snyder B (1993) Ceruloplasmin levels in the human superior temporal gyrus in aging and Alzheimer's disease. Neurosci Lett 159:88-90.

De Silva DM, Askwith CC, Kaplan J (1996) Molecular mechanisms of iron uptake in eukaryotes. Physiol Rev 76:31-47.

Donovan A, Brownlie A, Zhou Y, Shepard J, Pratt SJ, Moynihan J, Paw BH, Drejer A, Barut B, Zapata A, Law TC, Brugnara C, Lux SE, Pinkus GS, Pinkus JL, Kingsley PD, Palis J, Fleming MD, Andrews NC, Zon LI (2000) Positional cloning of zebrafish ferroportin1 identifies a conserved vertebrate iron exporter. Nature 403:776-781.

Fleming RE, Gitlin JD (1990) Primary structure of rat ceruloplasmin and analysis of tissue-specific gene expression during development. J Biol Chem 265:7701-7707.

Frazer DM, Vulpe CD, McKie AT, Wilkins SJ, Trinder D, Cleghorn GJ, Anderson GJ (2001) Cloning and gastrointestinal expression of rat hephaestin: relationship to other iron transport proteins. Am J Physiol Gastrointest Liver Physiol 281:G931-G939.

Frey D, Schneider C, Xu L, Borg J, Spooren W, Caroni P (2000) Early and selective loss of neuromuscular synapse subtypes with low sprouting competence in motoneuron diseases. J Neurosci 20:2534-2542.

Gerlach M, Ben-Shachar D, Riederer P, Youdim MBH (1994) Altered brain metabolism of iron as a cause of neurodegenerative diseases? J Neurochem 63:793-807.

Gitlin JD (1998) Aceruloplasminemia. Pediatr Res 44:271-276.

Gutteridge JM (1992) Iron and oxygen radicals in brain. Ann Neurol 32:S16-S21.

Han J, Day JR, Thomson K, Connor JR, Beard JL (2000) Iron deficiency alters $\mathrm{H}$ - and $\mathrm{L}$-ferritin expression in rat brain. Cell Mol Biol 46:517-528.

Hansen MB, Nielsen SE, Berg K (1989) Reexamination and further development of a precise and rapid dye method for measuring cell growth/cell kill. J Immunol Methods 119:203-210.

Harris ZL, Takahashi Y, Miyajima H, Serizawa M, MacGillivary RT, Gitlin JD (1995) Aceruloplasminemia: molecular characterization of this disorder of iron metabolism. Proc Natl Acad Sci USA 92:2539-2543.

Harris ZL, Durley AP, Man TK, Gitlin JD (1999) Targeted gene disruption reveals an essential role for ceruloplasmin in cellular iron efflux. Proc Natl Acad Sci USA 96:10812-10817.

Hellman NE, Kono S, Miyajima H, Gitlin JD (2002) Biochemical analysis of a missense mutation in aceruloplasminemia. J Biol Chem 277:1375-1380.

Hussain S, Slikker Jr W, Ali SF (1995) Age-related changes in antioxidant enzymes, superoxide dismutase, catalase, glutathione peroxidase and glutathione in different regions of mouse brain. Int J Dev Neurosci 13:811-817.

Hyslop PA, Zhang Z, Pearson DV, Phebus LA (1995) Measurement of striatal $\mathrm{H}_{2} \mathrm{O}_{2}$ by microdialysis following global forebrain ischemia and reperfusion in the rat: correlation with the cytotoxic potential of $\mathrm{H}_{2} \mathrm{O}_{2}$ in vitro. Brain Res 671:181-186.

Joyner AL (1993) Gene targeting: a practical approach. Oxford: Oxford UP.

Klomp LW, Gitlin JD (1996) Expression of the ceruloplasmin gene in the human retina and brain: implications for a pathogenic model in aceruloplasminemia. Hum Mol Genet 5:1989-1996.

Klomp LW, Farhangrazi ZD, Dugan LL, Gitlin JD (1996) Ceruloplasmin gene expression in the murine central nervous system. J Clin Invest 98:207-215.

Levin LA, Geszvain KM (1998) Expression of ceruloplasmin in the retina: induction after optic nerve crush. Invest Ophthalmol Vis Sci 39:157-163.

Liu C, Weaver DR, Strogatz SH, Reppert SM (1997) Cellular construction of a circadian clock: period determination in the suprachiasmatic nuclei. Cell 91:855-860.

Malecki EA, Devenyi AG, Beard JL, Connor JR (1999) Existing and emerging mechanisms for transport of iron and manganese to the brain. Neurosci Res 56:113-122.

McKie AT, Marciani P, Rolfs A, Brennan K, Wehr K, Barrow D, Miret S, Bomford A, Peters TJ, Farzaneh F, Hediger MA, Hentze MW, Simpson RJ (2000) A novel duodenal iron-regulated transporter, IREG1, implicated in the basolateral transfer of iron to the circulation. Mol Cell 5:299-309.

Mittal B, David S (1994) A monoclonal antibody that recognizes an adhesion molecule expressed by certain cells of neuroectodermal and mesenchymal origin. Mol Cell Neurosci 5:63-77.

Miyajima H, Nishimura Y, Mizoguchi K, Sakamoto M, Shimizu T, Honda N (1987) Familial apoceruloplasmin deficiency associated with blepharospasm and retinal degeneration. Neurology 37:761-767.

Morita H, Ikeda S, Yamamoto K, Morita S, Yoshida K, Nomoto S, Kato M, Yanagisawa N (1995) Hereditary ceruloplasmin deficiency with hemosiderosis: a clinicopathological study of a Japanese family. Ann Neurol 37:646-656.

Okamoto N, Wada S, Oga T, Kawabata Y, Baba Y, Habu D, Takeda Z, Wada Y (1996) Hereditary ceruloplasmin deficiency with hemosiderosis. Hum Genet 97:755-758

Olanow CW (1993) A radical hypothesis for neurodegeneration. Trends Neurosci 16:439-444.

Osaki S, Johnson DA, Frieden E (1966) The possible significance of the ferrous oxidase activity of ceruloplasmin in normal human serum. J Biol Chem 241:2746-2751.

Ousman S, David S (2000) Lysophosphatidylcholine induces rapid recruitment and activation of macrophages in the adult mouse spinal cord. Glia 30:92-104.

Palmer C, Menzies SL, Roberts RL, Pavlick G, Connor JR (1999) Changes in iron histochemistry after hypoxic-ischemic brain injury in the neonatal rat. J Neurosci Res 56:60-71.

Patel BN, David S (1997) A novel glycosylphosphatidylinositol-anchored form of ceruloplasmin is expressed by mammalian astrocytes. J Biol Chem 272:20185-20190.

Patel BN, Dunn RJ, David S (2000) Alternative RNA splicing generates 
a glycosylphosphatidylinositol-anchored form of ceruloplasmin in mammalian brain. J Biol Chem 275:4305-4310.

Richardson DR (1999) Role of ceruloplasmin and ascorbate in cellular iron release. J Lab Clin Med 134:454-465.

Roskams AJ, Connor JR (1992) Transferrin receptor expression in myelin deficient (md) rats. J Neurosci Res 31:421-427.

Smith MA, Harris PL, Sayre LM, Perry G (1997) Iron accumulation in Alzheimer disease is a source of redox-generated free radicals. Proc Natl Acad Sci USA 94:9866-9868.

Steele PM, Medina JF, Nores WL, Mauk MD (1998) Using genetic mutations to study the neural basis of behavior. Cell 95:879-882.

Surai PF, Speake BK, Noble RC, Sparks NH (1999) Tissue-specific antioxidant profiles and susceptibility to lipid peroxidation of the newly hatched chick. Biol Trace Elem Res 68:63-78.

Torrance JD, Bothwell TH (1980) Tissue iron stores. In: Methods in hematology: iron (Cook JD, ed), pp 90-115. New York: Churchill Livingstone.
Vulpe CD, Kuo YM, Murphy TL, Cowley L, Askwith C, Libina N, Gitschier and Anderson GJ (1999) Hephaestin, a ceruloplasmin homologue implicated in intestinal iron transport, is defective in the sla mouse. Nat Genet 21:195-199.

Williams K, Wilson MA, Bressler J (2000) Regulation and developmental expression of the divalent metal-iron transporter in the rat brain. Cell Mol Biol 46:563-571.

Winterbourn CC (1995) Toxicity of iron and hydrogen peroxide: the Fenton reaction. Toxicol Lett 82-83:969-974.

Yoshida K, Furihata K, Takeda S, Nakamura A, Yamamoto K, Morita H, Hiyamuta S, Ikeda S, Shimizu N, Yanagisawa N (1995) A mutation in the ceruloplasmin gene is associated with systemic hemosiderosis in humans. Nat Genet 9:267-272.

Young SP, Fahmy M, Golding S (1997) Ceruloplasmin, transferrin and apotransferrin facilitate iron release from human liver cells. FEBS Lett 411:93-96.

Zahs KR, Bigornia V, Deschepper CF (1993) Characterization of "plasma proteins" secreted by cultured rat macroglial cells. Glia 7:121-133. 